\title{
Cross-cultural adaptation and validation of the 3D-CAM Chinese version in surgical ICU patients
}

\author{
Dong-Liang Mu' ${ }^{1}$, Pan-Pan Ding ${ }^{1}$, Shu-Zhe Zhou ${ }^{2}$, Mei-Jing Liu' ${ }^{1}$, Xin-Yu Sun ${ }^{*}$, Xue-Ying Li ${ }^{3}$ and Dong-Xin Wang ${ }^{1}$
}

\begin{abstract}
Background: Accurate diagnosis of delirium is very important for prevention and treatment. Present study was designed to validate the 3-Minute Diagnostic Interview for CAM-defined Delirium Chinese version (3D-CAM-CN) in surgical ICU patients.
\end{abstract}

Methods: In this prospective diagnostic study, the 3D-CAM was translated into Chinese with culture adaption. Two interviewers (Roles A and B) independently administrated 3D-CAM-CN assessment in adult patients from postoperative days 1 to day 3. At the meantime, a panel of psychiatrists diagnosed delirium according to the Diagnostic and Statistical Manual of Mental Disorders-fifth edition as the reference standard. The sensitivity and specificity were calculated to analyze the diagnostic character of the 3D-CAM-CN. Kappa coefficient was used to evaluate interrater reliability.

Results: Two hundred forty-five adult patients were assessed for at least 2 days, resulting a total of 647 pairedassessments. When compared with the reference standard, the sensitivity and specificity of the 3D-CAM-CN assessment were 87.2 and $96.7 \%$, respectively, by Role A and 84.6 and $97.4 \%$, respectively, by Role B, with good interrater reliability (Kappa coefficient $=0.82, P<0.001$ ). It also performed well in patients with mild cognitive impairment, with the sensitivity from 85.7 to $100 \%$ and the specificity from 95.7 to $96.4 \%$.

Conclusion: Our results showed that the 3D-CAM-CN can be used as a reliable and accurate instrument for delirium assessment in surgical patients.

Trial registration: This trail was approved by the Clinical Research Ethic Committee of Peking University First Hospital (No. 2017-1321) and registered on Chinese clinical trial registry on July 6, 2017 (ChiCTR-OOC-17011887).

Keywords: Delirium, Diagnosis, Screening tool, 3D-CAM, Chinese version, validation, Chinese

\section{Background}

According to the Diagnostic and Statistical Manual of Mental Disorders-fifth edition (DSM-5), delirium is a transient brain syndrome that develops over a short period of time and is characterized by fluctuating disturbances in attention, awareness and cognition [1]. The

\footnotetext{
${ }^{*}$ Correspondence: sunxinyu@bjmu.edu.cn

${ }^{2}$ Department of Geriatric Psychiatry, Peking University Sixth Hospital, Beijing 100191, China

Full list of author information is available at the end of the article
}

reported incidence varies from 11.2 to $23.0 \%$ in general patients and is up to $50.6 \%$ in those admitted to the intensive care unit (ICU) after major surgery [2-4]. The occurrence of delirium is associated with worse outcomes, including prolonged lengths of stay in ICU and hospital, increased postoperative complications and inhospital mortality, as well as shortened long-term survival and worsened quality of life in long-term survivors [2, 3, 5-7]. The development of postoperative delirium is a result of multiple factors, including predisposing

C C The Author(s). 2020 Open Access This article is licensed under a Creative Commons Attribution 4.0 International License, which permits use, sharing, adaptation, distribution and reproduction in any medium or format, as long as you give appropriate credit to the original author(s) and the source, provide a link to the Creative Commons licence, and indicate if changes were made. The images or other third party material in this article are included in the article's Creative Commons licence, unless indicated otherwise in a credit line to the material. If material is not included in the article's Creative Commons licence and your intended use is not permitted by statutory regulation or exceeds the permitted use, you will need to obtain permission directly from the copyright holder. To view a copy of this licence, visit http://creativecommons.org/licenses/by/4.0/ The Creative Commons Public Domain Dedication waiver (http://creativecommons.org/publicdomain/zero/1.0/) applies to the data made available in this article, unless otherwise stated in a credit line to the data. 
factors (such as old age, cognitive deficit, preexisting comorbidities, etc.) and precipitating factors (such as surgical trauma, pain, opioids, and surgery-related stress response) [8].

Early diagnosis is essential for delirium prevention and treatment [8]. Unfortunately, underestimation and misdiagnosis of delirium are common and the rate may reach 50 to $70 \%$ [9-11]. The DSM-5 is the gold standard for diagnosing delirium [1]. However, the criteria of DSM-5 lack practical and standardized assessment methods for attention, awareness and cognition. Its proper use requires professional psychiatric background and training [12, 13]. To facilitate delirium diagnosis, several bedside assessment tools have been designed for non-psychiatric clinicians, such as the Confusion Assessment Method (CAM), the CAM for the Intensive Care Unit (CAM-ICU) and the 3-Minute Diagnostic Interview for CAM-defined Delirium (3D-CAM) [14-16]. Of these, the CAM is the most widely used delirium assessment tool, but it still has a defect in inconsistence of diagnostic criteria and substantial training is required to guarantee the quality of assessment [14, 17]. To overcome this defect, the 3D-CAM is derived from the CAM and reconstructed with definite criteria for administration [16]. In its original validation study, the 3D-CAM performs well in elderly patients with high sensitivity (93 to $96 \%$ ) and specificity (86 to $96 \%$ ) [16].

The aim of this study was to translate the 3D-CAM into Chinese and to validate the 3D-CAM Chinese version (3D-CAM-CN) in surgical patients.

\section{Methods}

This was a prospective diagnostic study to validate the reliability of the 3D-CAM-CN in surgical patients. The study protocol was approved by the Clinical Research Ethics Committee of Peking University First Hospital (2017-1321) and registered on Chinese Clinical Trial Registry on July 6, 2017 (http://www.chictr.org.cn, ChiCTR-OOC-17011887). The study was administrated in Peking University First Hospital. Written informed consents were obtained from all enrolled patients or their surrogates.

\section{Translation and back translation}

After approval by Dr. Edward R. Marcantonio, [16] translation and back-translation were performed according to the principles of translation and cultural adaptation of patient report outcome measures [18, 19]. Firstly, the original 3D-CAM was translated into Chinese by two anesthesiologists (DLM and DXW) and one psychiatrist (XYS) independently. The three translational versions then were discussed and merged into a final version. Back translation was performed in regardless of any information from its original version. Both the translated and back translated versions (Supplement 1) were sent to Dr. Marcantonio for approval.

To be noted, the translation of items 6 and 7 was adapted according to Chinese culture (Supplement 2). In Chinese, answers to the original items 6 and 7 will be "xingqi (week) 6, xingqi 5, ... and xingqi tian (week day)" and "month 12 , month $11, \ldots$, and month 1 " respectively. This means there are only numeric changes of the word sequence and the difficulty of the tests will be decreased. After discussion with a panel of psychiatrists and approval from Dr. Marcantonio, we adopted "seasons backward" and "minus calculation" instead of the original item 6 and 7, respectively (Supplement 2). Both the recall of seasons in a backward sequence and the minus calculation have been used to test attention in several psychometric instruments and have been validated in Chinese population [20-22].

\section{Participants}

The inclusion criteria were adult patients (age $\geq 18$ years old) who were admitted to the ICU after surgery with a predicted length of stay for more than $48 \mathrm{~h}$. Those who met any of the following criteria were excluded: (1) refused to participate; (2) history of dementia, schizophrenia, epilepsy, Parkinsonism, or any other cerebral disease that might impede communication; (3) hearing/vision impairment, language barrier or endotracheal intubation which might impede communication; or (4) coma or deep sedation.

\section{Enrollment and baseline data collection}

One day before surgery, researchers visited patients who met the inclusion and exclusion criteria. Study protocol and related procedures were explained thoroughly to potential participants. After obtaining written informed consent, baseline data were collected which included demographic characteristics, current diagnosis and history of comorbidities. Cognitive function was assessed with the Mini-Mental State Examination (MMSE, total range 0-30, with higher score indicating better cognitive function) [22]. Patients with a MMSE score of less than 27 were considered to have preoperative cognitive impairment $[22,23]$.

\section{Delirium assessment}

\section{Delirium assessment with the 3D-CAM-CN}

Before the study period, all researchers participated in a 3-h training program on delirium and delirium assessment. The theoretical lecture session included the clinical manifestations and diagnosis of delirium, the structure and content of the 3D-CAM-CN, as well as the key points in administrating the 3D-CAM-CN. In the practical training session, two interviewers (PPD and MJL, anesthesia residents) firstly administered the instrument to each other and then to actual patients; the 
training continued until the diagnosis of delirium reached $100 \%$ agreement with the panel of psychiatrists.

During the study period, the two interviewers (Role A $[\mathrm{PPD}]$ and Role $\mathrm{B}[\mathrm{MJL}]$ ) were designated to assess delirium with the 3D-CAM-CN. To reduce bias, random numbers were created by a biostatistician to determine the sequence of assessment (i.e., A-B or B-A). The first interviewer asked question at each time during the assessment; the two interviewers then completed delirium assessment independently and were blinded to each other's result. Patients were consecutively followed-up and repeatedly assessed for delirium from postoperative days 1 to 3 between 18:00 and 20:00. All assessment processes were recorded by video.

\section{Delirium assessment with the DSM-5}

One of the psychiatrist panel members (SZZ, QG and QT), who was blinded to the 3D-CAM-CN assessment results, evaluated the patients according to the criteria of DSM-5 within $3 \mathrm{~min}$ after the 3D-CAM assessment [1]. The interview process was also recorded by video. The panel then reviewed the video together and made a decision if the patient suffered from delirium. All diagnostic results were reconfirmed by a consultant psychiatrist (XYS). The final results were considered as the reference standards.

\section{Validation of adapted items 6 and 7}

Each time during delirium assessment, the psychiatrist panel also made a special examination of attention and judged if the patient had inattention. This was considered as the reference standard for adapted items 6 and 7. The sensitivity and specificity were calculated to test the diagnostic characteristics of these adapted items.

\section{Statistical analysis}

\section{Sample size calculation}

In our previous study, the incidence of delirium after noncardiac surgery was about 15\% [24]. We assumed that the width of confidence interval was 0.2 ; with the sensitivity and specificity set at $90 \%$, we need to enroll 230 and 41 patients, respectively. Considering a 5\% loss to follow-up rate, we planned to enroll 245 patients.

\section{Outcome analysis}

Continuous data was presented as mean (standard deviation, SD) or median (interquartile range). Categorical data was presented as number (percentage). The sensitivity and specificity were calculated to analyze the diagnostic characteristics of 3D-CAM-CN in comparison with the reference standard. The sensitivity and specificity of adapted items 6 and 7 were also calculated according to the reference standard. Kappa coefficient was employed to analyze the interrater reliability between two interviewers. All statistical analyses were performed with SPSS 25.0 (IBM SPSS Inc., Chicago, IL, USA). Twotailed $P$ value of less than 0.05 was considered statistically significant.

\section{Results \\ Patients}

From July 19, 2017 to September 10, 2017, 293 patients were screened. Of these, 245 gave written informed consents and were enrolled; all these patients completed the study and were included in final analyses (Fig. 1). The enrolled patients had a mean age of 73.0 (SD 10.0) years; $22.0 \%$ of them $(54 / 245)$ had preoperative cognitive impairment. Baseline data were presented in Table 1.

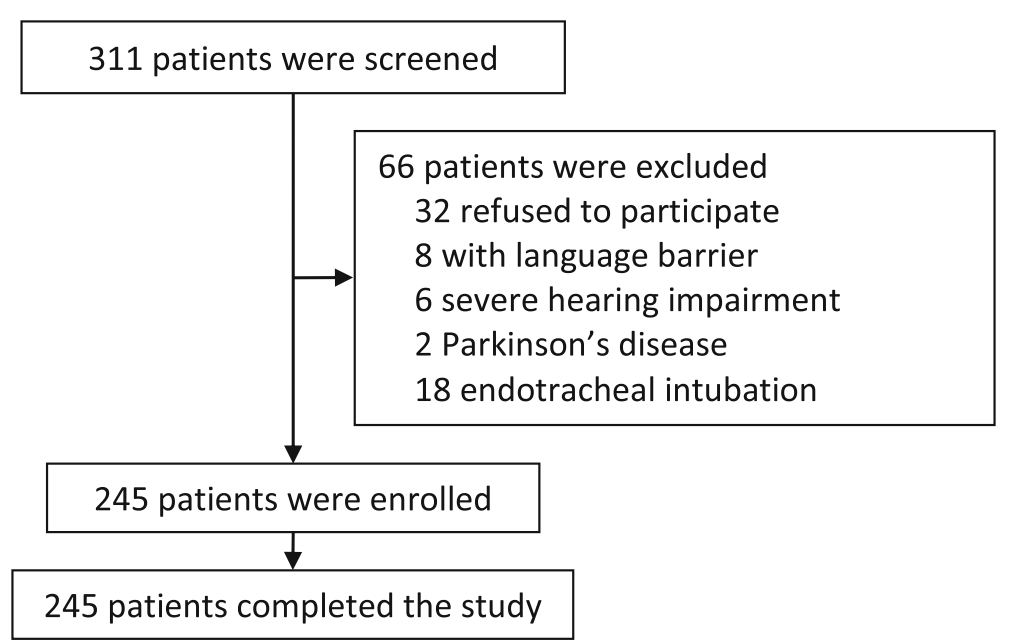

Fig. 1 Flowchart of present study 
Table 1 Baseline and perioperative data

\begin{tabular}{|c|c|}
\hline Variables & Enrolled patients $(\boldsymbol{n}=245)$ \\
\hline Age, year & $73.0(10.0)$ \\
\hline Female gender & $92(37.6)$ \\
\hline Height, cm & $165.6(8.3)$ \\
\hline Body weight, kg & $65.9(11.3)$ \\
\hline \multicolumn{2}{|l|}{ Previous medical history } \\
\hline Stroke & $23(9.4)$ \\
\hline Hypertension & $142(58.0)$ \\
\hline Coronary heart disease & $81(33.1)$ \\
\hline Arrhythmia & $31(12.7)$ \\
\hline Pneumonia & $1(0.4)$ \\
\hline COPD & $9(3.7)$ \\
\hline Asthma & $5(2.0)$ \\
\hline Diabetics & $65(26.5)$ \\
\hline Hyperlipidemia & $2(0.8)$ \\
\hline Chronic renal failure & $14(5.7)$ \\
\hline Hypothyroidism & $5(2.0)$ \\
\hline Hyperthyroidism & $2(0.8)$ \\
\hline MMSE, score & $27.5(2.8)$ \\
\hline MMSE $<27$ & $54(22.0)$ \\
\hline \multicolumn{2}{|l|}{ Type of surgery } \\
\hline Gastrointestinal & $67(27.3)$ \\
\hline Thoracic & $22(9.0)$ \\
\hline Orthopedic & $45(18.4)$ \\
\hline Urological & $111(45.3)$ \\
\hline APACHE II, score & $12.5(4.3)$ \\
\hline
\end{tabular}

Data was presented as mean (standard deviation) or number (percentage) COPD chronic obstructive pulmonary disease; MMSE Mini-Mental State Examination; APACHE Acute Physiology and Chronic Health Evaluation

\section{Detection of delirium}

Each patient was assessed for at least two consecutive days, resulting 647 paired assessments. According to the DSM-5, the psychiatrist panel reported that 9.8\% (24/ 245) of patients suffered from at least one episode of delirium during the interview assessment. The incidence of delirium reported by Roles A and B was 12.7\% (31/245) and $12.2 \%(30 / 245)$, respectively.

\section{Validation of the 3D-CAM-CN assessment}

When compared with the reference standard, the sensitivity and specificity of the 3D-CAM-CN assessment by Role A were $87.2 \%$ (95\% CI 76.7 to $97.7 \%$ ) and $96.7 \%$ (95\% CI 95.3 to $98.1 \%$ ), respectively; and those by Role B were $84.6 \%$ (95\% CI 73.3 to $95.9 \%$ ) and $97.4 \%$ (95\% CI 96.1 to $98.6 \%$ ), respectively (Table 2 ). There was a good interrater reliability between Roles A and B (Kappa coefficient $=0.820, P<0.001$ ).

\section{Exploratory analysis of validation of the 3D-CAM-CN assessment}

In all enrolled patients, 264 paired assessments were completed in the ICU and 383 in the general ward. The 3D-CAM-CN performed well in both settings with the sensitivity ranged from 82.6 to $93.8 \%$ and the specificity from 96.7 to $98.1 \%$, respectively (Table 3 ).

In 191 patients with normal cognitive function, 502 paired assessments were completed. The sensitivity of 3D-CAM-CN assessment ranged from 81.3 to $87.5 \%$, and the specificity from 97.0 to $97.7 \%$. In 54 patients with cognitive impairment, 145 paired assessments were completed. The sensitivity of 3D-CAM-CN assessment ranged from 85.7 to $100 \%$, and specificity from 95.7 to 96.4\% (Table 3).

Validation of the assessment with adapted items 6 and 7 After culture adaptation, items 6 and 7 showed acceptable sensitivity and specificity in validation test (for item 6: sensitivity 71.7 to $73.9 \%$, specificity 78.0 to $78.9 \%$; for item 7: sensitivity $82.6 \%$, specificity 64.9 to $65.1 \%$ ). The Kappa coefficient of interrater reliability was 0.943 and 0.822 , respectively (all $P<0.001$ ) (Table 4 ).

\section{Discussion}

Our results showed that the 3D-CAM-CN can be used as a reliable instrument for delirium assessment in patients after surgery. It performed well in patients with

Table 2 Validation of the 3D-CAM-CN assessment

\begin{tabular}{|c|c|c|c|c|c|c|}
\hline \multirow{2}{*}{$\begin{array}{l}\text { Reference } \\
\text { standard by } \\
\text { DSM-5 } \\
\end{array}$} & \multicolumn{3}{|l|}{ Role A } & \multicolumn{3}{|l|}{ Role B } \\
\hline & Delirium (yes) & Delirium (no) & Total & Delirium (yes) & Delirium (no) & Total \\
\hline Delirium (yes) & 34 & 5 & 39 & 33 & 6 & 39 \\
\hline Delirium (no) & 20 & 588 & 608 & 16 & 592 & 608 \\
\hline Sensitivity & \multicolumn{3}{|c|}{$87.2 \%(76.7-97.7 \%)$} & \multicolumn{3}{|c|}{$84.6 \%$ (73.3-95.9\%) } \\
\hline Specificity & \multicolumn{3}{|c|}{$96.7 \%(95.3-98.1 \%)$} & \multicolumn{3}{|c|}{$97.4 \%$ (96.1-98.6\%) } \\
\hline Kappa & \multicolumn{6}{|c|}{0.820} \\
\hline$P$ value & \multicolumn{6}{|c|}{$<0.001$} \\
\hline
\end{tabular}

Results are presented as number and estimate (95\% confidence interval) 
Table 3 Exploratory analysis of validation of the 3D-CAM-CN assessment

\begin{tabular}{|c|c|c|c|c|c|c|c|c|c|c|c|c|}
\hline \multirow{3}{*}{$\begin{array}{l}\text { Reference standard } \\
\text { by the DSM-5 }\end{array}$} & \multicolumn{6}{|l|}{ In the ICU } & \multicolumn{6}{|c|}{ In the general ward } \\
\hline & \multicolumn{3}{|l|}{ Role A } & \multicolumn{3}{|l|}{ Role B } & \multicolumn{3}{|l|}{ Role A } & \multicolumn{3}{|l|}{ Role B } \\
\hline & $\begin{array}{l}\text { Delirium } \\
\text { (yes) }\end{array}$ & $\begin{array}{l}\text { Delirium } \\
\text { (no) }\end{array}$ & Total & $\begin{array}{l}\text { Delirium } \\
\text { (yes) }\end{array}$ & $\begin{array}{l}\text { Delirium } \\
\text { (no) }\end{array}$ & Total & $\begin{array}{l}\text { Delirium } \\
\text { (yes) }\end{array}$ & $\begin{array}{l}\text { Delirium } \\
\text { (no) }\end{array}$ & Total & $\begin{array}{l}\text { Delirium } \\
\text { (yes) }\end{array}$ & $\begin{array}{l}\text { Delirium } \\
\text { (no) }\end{array}$ & Total \\
\hline Delirium (yes) & 19 & 4 & 23 & 19 & 4 & 23 & 15 & 1 & 16 & 19 & 4 & 23 \\
\hline Delirium (no) & 8 & 233 & 241 & 9 & 232 & 241 & 12 & 355 & 367 & 9 & 232 & 241 \\
\hline Sensitivity & \multicolumn{3}{|c|}{$82.6 \%(67.1-98.1 \%)$} & \multicolumn{3}{|c|}{$82.6 \%(67.1-98.1 \%)$} & \multicolumn{3}{|c|}{$93.8 \%(81.9-100 \%)$} & \multicolumn{3}{|c|}{$87.5 \%(71.3-100 \%)$} \\
\hline Specificity & \multicolumn{3}{|c|}{$96.7 \%(94.4-98.9 \%)$} & \multicolumn{3}{|c|}{$96.3 \%(93.9-98.7 \%)$} & \multicolumn{3}{|c|}{$96.7 \%(94.9-98.5 \%)$} & \multicolumn{3}{|c|}{$98.1 \%(96.7-99.5 \%)$} \\
\hline Kappa coefficient & \multicolumn{6}{|c|}{0.817} & \multicolumn{6}{|c|}{0.822} \\
\hline$P$ value & \multicolumn{6}{|c|}{$<0.001$} & \multicolumn{6}{|c|}{$<0.001$} \\
\hline \multirow{3}{*}{$\begin{array}{l}\text { Reference standard } \\
\text { by the DSM-5 }\end{array}$} & \multicolumn{6}{|c|}{ In patients with normal cognition } & \multicolumn{6}{|c|}{ In patients with cognitive impairment } \\
\hline & \multicolumn{3}{|l|}{ Role A } & \multicolumn{3}{|l|}{ Role B } & \multicolumn{3}{|l|}{ Role A } & \multicolumn{3}{|l|}{ Role B } \\
\hline & $\begin{array}{l}\text { Delirium } \\
\text { (yes) }\end{array}$ & $\begin{array}{l}\text { Delirium } \\
\text { (no) }\end{array}$ & Total & $\begin{array}{l}\text { Delirium } \\
\text { (yes) }\end{array}$ & $\begin{array}{l}\text { Delirium } \\
\text { (no) }\end{array}$ & Total & $\begin{array}{l}\text { Delirium } \\
\text { (yes) }\end{array}$ & $\begin{array}{l}\text { Delirium } \\
\text { (no) }\end{array}$ & Total & $\begin{array}{l}\text { Delirium } \\
\text { (yes) }\end{array}$ & $\begin{array}{l}\text { Delirium } \\
\text { (no) }\end{array}$ & Total \\
\hline Delirium (yes) & 28 & 4 & 32 & 26 & 6 & 32 & 6 & 1 & 7 & 7 & 0 & 7 \\
\hline Delirium (no) & 14 & 456 & 470 & 11 & 459 & 470 & 6 & 132 & 138 & 5 & 133 & 138 \\
\hline Sensitivity & \multicolumn{3}{|c|}{$87.5 \%$ (76.0-99.0\%) } & \multicolumn{3}{|c|}{$81.3 \%$ (67.7-94.8\%) } & \multicolumn{2}{|c|}{$85.7 \%$ (59.8-100\%) } & & \multicolumn{2}{|c|}{$100 \%$ (100-100\%) } & \\
\hline Specificity & \multicolumn{3}{|c|}{$97.0 \%$ (95.5-98.6\%) } & \multicolumn{3}{|c|}{$97.7 \%$ (96.3-99.0\%) } & \multicolumn{2}{|c|}{ 95.7\% (92.2-99.1\%) } & & \multicolumn{2}{|c|}{$96.4 \%$ (93.3-99.5\%) } & \\
\hline Kappa coefficient & & & 0.8 & 49 & & & & & 0.7 & 27 & & \\
\hline$P$ value & & & $<0$ & 001 & & & & & $<0$. & 001 & & \\
\hline
\end{tabular}

Results are presented as number and estimate ( $95 \%$ confidence interval)

mild cognitive impairment or in the ICU settings without endotracheal intubation.

More than 28 kinds of assessment instruments are constructed and introduced to facilitate delirium screening $[17,25]$. These instruments significantly improved the efficacy and accuracy of delirium diagnosis. Of these, the CAM was proposed to be the most efficient one $[17,25]$. However, one deficit of the CAM is that there exists discrepancy in diagnostic criteria between interviewers even after substantial training [17]. For example, question 2 of the CAM is designed to access if a patient experiences inattention; but there are no clear criteria and predefined assessment method [26]. The interviewer's skill of interrogation will significantly influence assessment result [17]. The 3D-CAM is derived from the CAM and provides a brief and structured assessment algorithm to accelerate and simplify the process of diagnosis [16].

The present study validated the efficacy and accuracy of the 3D-CAM-CN in surgical patients in both the ICU setting (without endotracheal intubation) and the general ward. Several bed-side instruments have been used for diagnosing delirium in ICU patients, such as the CAM-ICU and the Intensive Care Delirium Screening Checklist (ICDSC) [27]. However, these instruments are seldom compared with the 3D-CAM in ICU patients. In a prospective cohort study of 101 non-ICU geriatric patients (aged $\geq 75$

Table 4 Validation of adapted items 6 and 7 assessment

\begin{tabular}{|c|c|c|c|c|c|c|c|c|c|c|c|c|}
\hline \multirow{3}{*}{$\begin{array}{l}\text { Reference } \\
\text { standard by } \\
\text { psychiatrists }\end{array}$} & \multicolumn{6}{|c|}{ Item 6 (seasons of year, backward) } & \multicolumn{6}{|c|}{ Item 7 (minus calculation) } \\
\hline & \multicolumn{3}{|l|}{ Role A } & \multicolumn{3}{|l|}{ Role B } & \multicolumn{3}{|l|}{ Role A } & \multicolumn{3}{|l|}{ Role B } \\
\hline & $\begin{array}{l}\text { Inattention } \\
\text { (yes) }\end{array}$ & $\begin{array}{l}\text { Inattention } \\
\text { (no) }\end{array}$ & Total & $\begin{array}{l}\text { Inattention } \\
\text { (yes) }\end{array}$ & $\begin{array}{l}\text { Inattention } \\
\text { (no) }\end{array}$ & Total & $\begin{array}{l}\text { Inattention } \\
\text { (yes) }\end{array}$ & $\begin{array}{l}\text { Inattention } \\
\text { (no) }\end{array}$ & Total & $\begin{array}{l}\text { Inattention } \\
\text { (yes) }\end{array}$ & $\begin{array}{l}\text { Inattention } \\
\text { (no) }\end{array}$ & Total \\
\hline $\begin{array}{l}\text { Inattention } \\
\text { (yes) }\end{array}$ & 33 & 13 & 46 & 34 & 12 & 46 & 38 & 8 & 46 & 38 & 8 & 46 \\
\hline $\begin{array}{l}\text { Inattention } \\
\text { (no) }\end{array}$ & 127 & 474 & 601 & 132 & 469 & 601 & 211 & 390 & 601 & 210 & 391 & 601 \\
\hline Sensitivity & \multicolumn{2}{|c|}{$71.7 \%(58.7-84.8 \%)$} & & \multicolumn{3}{|c|}{$73.9 \%(61.2-86.6 \%)$} & \multicolumn{2}{|c|}{$82.6 \%(71.7-93.6 \%)$} & & \multicolumn{2}{|c|}{$82.6 \%$ (71.7-93.6\%) } & \\
\hline Specificity & \multicolumn{2}{|c|}{$78.9 \%(75.6-82.1 \%)$} & & \multicolumn{3}{|c|}{$78.0 \%(74.7-81.3 \%)$} & $64.9 \%(61.1-68$ & $8.7 \%)$ & & \multicolumn{2}{|c|}{$65.1 \%(61.2-68.9 \%)$} & \\
\hline Kappa & \multicolumn{6}{|c|}{0.943} & \multicolumn{6}{|c|}{0.822} \\
\hline$P$ value & \multicolumn{6}{|c|}{$<0.001$} & \multicolumn{6}{|c|}{$<0.001$} \\
\hline
\end{tabular}

Results are presented as number and estimate (95\% confidence interval) 
years), the authors reported that the $3 \mathrm{D}-\mathrm{CAM}$ was superior than the CAM-ICU in diagnosing delirium [28].

Delirium assessment in patients with cognitive impairment or dementia is a challenging task [29]. Lack of an efficient instrument is considered the main reason of mis- and underdiagnosis of delirium in this population $[29,30]$. Marcantonio and colleagues [16] reported that the sensitivity and specificity of the 3D-CAM in dementia patients was $96 \%$ and of $86 \%$, respectively. Our study also confirmed that the 3D-CAM-CN performed well in patients with mild cognitive impairment, with high sensitivity (85.7 to $100 \%)$ and specificity (95.7 to $96.4 \%)$.

Inattention is considered as a core characteristic of delirium by the DSM-5 [1]. Backward recall of weekdays and months is used to detect inattention in the original version of the 3D-CAM. However, in Chinese, answers to the original items 6 and 7 are too simple to guarantee their sensitivity and specificity. In the present study, two alternative tools were adopted for inattention assessment from the MMSE and the Loewenstein Occupational Therapy Cognitive Assessment Battery-second edition [20-22]. In our results, the adapted items 6 and 7 showed good sensitivity and specificity in detecting inattention with high interrater reliability.

The strength of our study included the sufficient prestudy training, the strict reference standards provided by a panel of psychiatrists, and the sufficient sample size. However, limitations also exist. The present study was performed in a single center and only enrolled patients after surgery. These may limit the generalizability of our results.

\section{Conclusions}

Our study confirmed that the 3D-CAM-CN can be used as a reliable and accurate instrument for delirium assessment in surgical patients. It performs well in nonintubated patients in the ICU and in those with mild cognitive impairment.

\section{Supplementary information}

Supplementary information accompanies this paper at https://doi.org/10. 1186/s12888-020-02544-w.

Additional file 1. Supplement 1 Back translation of 3D-CAM Chinese version

Additional file 2. Supplement 2. Culture adaptation of items 6 and 7

\footnotetext{
Abbreviations

3D-CAM: 3-Minute Diagnostic Interview for CAM-defined Delirium; 3D-CAMCN: 3-Minute Diagnostic Interview for CAM-defined Delirium Chinese version; ICU: Intensive care unit; DSM-5: Diagnostic and Statistical Manual of Mental Disorders-fifth edition; CAM: Confusion Assessment Method; CAM-ICU: CAM for the Intensive Care Unit; MMSE: Mini-Mental State Examination; ICDSC: Intensive Care Delirium Screening Checklist; SD: Standard deviation; $\mathrm{Cl}$ : Confidence interval
}

\section{Acknowledgements}

We greatly appreciate Drs. Qin Gao (Department of Psychiatry, Third People's Hospital of Fuyang) and Qi Tang (Department of Psychiatry, Zigong Mental Health (enter) for their help in study administration.

\section{Authors' contributions}

DLM, study design and administration, manuscript draft. PPD, SZZ, MJL, study administration. XYS, study design, administration and final approval of publication. XYL, statistical analysis. DXW, study design and manuscript revision. The author(s) read and approved the final manuscript.

\section{Funding}

This work was supported by National Key R\&D Program of China (2018YFC2001800). The sponsors have no role in the study design and conduct; the collection, management, analysis, and interpretation of the data; or the preparation and approval of the manuscript.

\section{Availability of data and materials}

The datasets used and/or analyzed during the current study are available from the corresponding author on reasonable request.

\section{Ethics approval and consent to participate}

The study protocol was approved by the Clinical Research Ethics Committee of Peking University First Hospital (2017-1321) and registered on Chinese Clinical Trial Registry on July 6, 2017 (http://www.chictr.org.cn, ChiCTR-OOC17011887). Written informed consents were obtained from all enrolled patients or their surrogates.

\section{Consent for publication}

Not applicable.

\section{Competing interests}

The authors declare that they have no competing interests.

\section{Author details}

'Department of Anesthesiology and Critical Care Medicine, Peking University First Hospital, Beijing, China. ${ }^{2}$ Department of Geriatric Psychiatry, Peking University Sixth Hospital, Beijing 100191, China. ${ }^{3}$ Department of Biostatistics, Peking University First Hospital, Beijing, China.

Received: 12 September 2019 Accepted: 11 March 2020

Published online: 24 March 2020

\section{References}

1. Association AP. Diagnostic and statistical manual of mental disorders. 5th ed. Arlington: American Psychiatric Association. 2013

2. Su X, Meng ZT, Wu XH, Cui F, Li HL, Wang DX, Zhu X, Zhu SN, Maze M, Ma D. Dexmedetomidine for prevention of delirium in elderly patients after non-cardiac surgery: a randomised, double-blind, placebo-controlled trial. Lancet (London, England). 2016;388(10054):1893-902.

3. Mu DL, Wang DX, Li LH, Shan GJ, Li J, Yu QJ, Shi CX. High serum cortisol level is associated with increased risk of delirium after coronary artery bypass graft surgery: a prospective cohort study. Crit Care (London, England). 2010;14(6):R238.

4. Mu DL, Zhang DZ, Wang DX, Wang G, Li CJ, Meng ZT, Li YW, Liu C, Li XY. Parecoxib supplementation to morphine analgesia decreases incidence of delirium in elderly patients after hip or knee replacement surgery: a randomized controlled trial. Anesth Analg. 2017:124(6):1992-2000

5. Ely EW, Shintani A, Truman B, Speroff T, Gordon SM, Harrell FE Jr, Inouye SK, Bernard GR, Dittus RS. Delirium as a predictor of mortality in mechanically ventilated patients in the intensive care unit. Jama. 2004; 291(14):1753-62.

6. Thomason JW, Shintani A, Peterson JF, Pun BT, Jackson JC, Ely EW. Intensive care unit delirium is an independent predictor of longer hospital stay: a prospective analysis of 261 non-ventilated patients. Crit Care (London, England). 2005;9(4):R375-81.

7. Zhang DF, Su X, Meng ZT, Li HL, Wang DX, Li XY, Maze M, Ma D. Impact of Dexmedetomidine on long-term outcomes after noncardiac surgery in elderly: 3-year follow-up of a randomized controlled trial. Ann Surg. 2018;270:356. 
8. Barr J, Fraser GL, Puntillo K, Ely EW, Gelinas C, Dasta JF, Davidson JE, Devlin JW, Kress JP, Joffe AM, et al. Clinical practice guidelines for the management of pain, agitation, and delirium in adult patients in the intensive care unit. Crit Care Med. 2013;41(1):263-306.

9. Spronk PE, Riekerk B, Hofhuis J, Rommes JH. Occurrence of delirium is severely underestimated in the ICU during daily care. Intensive Care Med. 2009;35(7):1276-80.

10. McCoy TH Jr, Snapper L, Stern TA, Perlis RH. Underreporting of delirium in statewide claims data: implications for clinical care and predictive modeling. Psychosomatics. 2016;57(5):480-8.

11. Chin YC, Koh GC, Tay YK, Tan CH, Merchant RA. Underdiagnosis of delirium on admission and prediction of patients who will develop delirium during their inpatient stay: a pilot study. Singap Med J. 2016; 57(1):18-21.

12. Meagher DJ, Morandi A, Inouye SK, Ely W, Adamis D, Maclullich AJ, Rudolph JL, Neufeld K, Leonard M, Bellelli G, et al. Concordance between DSM-IV and DSM-5 criteria for delirium diagnosis in a pooled database of 768 prospectively evaluated patients using the delirium rating scale-revised-98. BMC Med. 2014;12:164.

13. European Delirium Association ADS. The DSM-5 criteria, level of arousal and delirium diagnosis: inclusiveness is safer. BMC Med. 2014;12:141.

14. Inouye SK, van Dyck CH, Alessi CA, Balkin S, Siegal AP, Horwitz Rl. Clarifying confusion: the confusion assessment method. A new method for detection of delirium. Ann Intern Med. 1990;113(12):941-8.

15. Ely EW, Inouye SK, Bernard GR, Gordon S, Francis J, May L, Truman B, Speroff T, Gautam S, Margolin R, et al. Delirium in mechanically ventilated patients: validity and reliability of the confusion assessment method for the intensive care unit (CAM-ICU). Jama. 2001;286(21):2703-10.

16. Marcantonio ER, Ngo LH, O'Connor M, Jones RN, Crane PK, Metzger ED, Inouye SK. 3D-CAM: derivation and validation of a 3-minute diagnostic interview for CAM-defined delirium: a cross-sectional diagnostic test study. Ann Intern Med. 2014;161(8):554-61.

17. Wong CL, Holroyd-Leduc J, Simel DL, Straus SE. Does this patient have delirium?: value of bedside instruments. Jama. 2010;304(7):779-86.

18. Beaton DE, Bombardier C, Guillemin F, Ferraz MB. Guidelines for the process of cross-cultural adaptation of self-report measures. Spine. 2000; 25(24):3186-91.

19. Wild D, Grove A, Martin M, Eremenco S, McElroy S, Verjee-Lorenz A Erikson P. Principles of good practice for the translation and cultura adaptation process for patient-reported outcomes (PRO) measures: report of the ISPOR task force for translation and cultural adaptation. Value Health. 2005;8(2):94-104.

20. Yu ZZ, Jiang SJ, Li J, Bi S, Li F, Xie T, Wang R, Zhang XT. Clinical application of Loewenstein Occupational Therapy Cognitive Assessment Battery-Second Edition in evaluating of cognitive function of Chinese patients with poststroke aphasia. Chin Med Sci J. 2013;28(3):167-71.

21. Han Y, Liu Y, Zhang X, Tam W, Mao J, Lopez V. Chinese family caregivers of stroke survivors: determinants of caregiving burden within the first six months. J Clin Nurs. 2017;26(23-24):4558-66

22. Katzman R, Zhang MY, Ouang Ya Q, Wang ZY, Liu WT, Yu E, Wong SC, Salmon DP, Grant I. A Chinese version of the mini-mental state examination; impact of illiteracy in a Shanghai dementia survey. J Clin Epidemiol. 1988; 41(10):971-8.

23. Feng $L$, Chong MS, Lim WS, Ng TP. The modified mini-mental state examination test: normative data for Singapore Chinese older adults and its performance in detecting early cognitive impairment. Singap Med J. 2012; 53(7):458-62.

24. Liu P, Li YW, Wang XS, Zou X, Zhang DZ, Wang DX, Li SZ. High serum interleukin-6 level is associated with increased risk of delirium in elderly patients after noncardiac surgery: a prospective cohort study. Chin Med J. 2013;126(19):3621-7

25. van Velthuijsen EL, Zwakhalen SM, Warnier RM, Mulder WJ, Verhey FR, Kempen GI. Psychometric properties and feasibility of instruments for the detection of delirium in older hospitalized patients: a systematic review. Int J Geriatr Psychiatry. 2016;31(9):974-89.

26. I SK. The Confusion Assessment Method (CAM): Training Manual and Coding Guide. Boston: Hospital Elder Life Program; 2003.

27. Bilotta F, Lauretta MP, Borozdina A, Mizikov VM, Rosa G. Postoperative delirium: risk factors, diagnosis and perioperative care. Minerva Anestesiol. 2013;79(9):1066-76.
28. Kuczmarska A, Ngo LH, Guess J, O'Connor MA, Branford-White L, Palihnich K, Gallagher J, Marcantonio ER. Detection of delirium in hospitalized older general medicine patients: a comparison of the 3D-CAM and CAM-ICU. J Gen Intern Med. 2016;31(3):297-303.

29. Roden M, Simmons BB. Delirium superimposed on dementia and mild cognitive impairment. Postgrad Med. 2014;126(6):129-37.

30. Fick DM, Agostini JV, Inouye SK. Delirium superimposed on dementia: a systematic review. J Am Geriatr Soc. 2002;50(10):1723-32.

\section{Publisher's Note}

Springer Nature remains neutral with regard to jurisdictional claims in published maps and institutional affiliations.
Ready to submit your research? Choose BMC and benefit from:

- fast, convenient online submission

- thorough peer review by experienced researchers in your field

- rapid publication on acceptance

- support for research data, including large and complex data types

- gold Open Access which fosters wider collaboration and increased citations

- maximum visibility for your research: over $100 \mathrm{M}$ website views per year

At BMC, research is always in progress.

Learn more biomedcentral.com/submissions 